\title{
An Analysis of The Effect of Fashion Consciousness as A Mediating Factor on Hijab Fashion Consumption in Indonesia
}

\author{
Mayangsari Edastami ${ }^{1}$, Miyasto ${ }^{2}$ and Akhmad Affandi Mahfudz ${ }^{3}$
}

\begin{abstract}
This research aims to analyze the influence factors in fashion consciousness on consumers in Indonesia, especially in relation to consumption of hijab-fashion. These factors are religiosity, dressing style, source of knowledge, fashion motivation, and uniqueness also the fashion consciousness as a intervening variable. This study use a structural equation. The first interesting finding was that religiosity has a negative effect to hijab fashion consciousness. Furthermore, there is a positive significant influence on dressing style and fashion motivation in fashion consciousness, but there is no significant influence on the source of knowledge and the uniqueness in the fashion consciousness. This study also found that fashion consciousness has a significant effect on the consumption of hijab-fashion in Indonesia. By looking at the results of this study, it is hoped that it can be useful especially for hijab-fashion manufacturers and industry in Indonesia in considering a more effective strategy in attracting the attention of Muslim consumers in Indonesia. Producers are expected to be able to provide the consumer expectations, especially for religious consumers. Because religious consumers will be more critical in decision related to the selection of fashion models and consumption of hijab-fashion.
\end{abstract}

Keywords: Religiousity, Fashion Consciousness, Fashion Consumption

Abstrak. Penelitian ini bertujuan untuk menganalisis faktor-faktor yang mempengaruhi kesadaran mode pada konsumen di Indonesia, terutama dalam kaitannya dengan konsumsi busana muslimah. Faktor-faktor yang digunakan dalam penelitian ini adalah religiusitas, gaya berbusana, sumber pengetahuan, motivasi mode, dan keunikan busana, serta kesadaran mode sebagai variabel intervening. Penelitian ini menggunakan struktur equation model. Penelitian ini menemukan bahwa religiusitas memiliki pengaruh negatif terhadap kesadaran jilbab mode. Selain itu, ada pengaruh signifikan positif faktor gaya berpakaian dan motivasi mode terhadap kesadaran mode, tetapi tidak terdapat pengaruh signifikan faktor sumber pengetahuan dan keunikan terhadap kesadaran mode. Penelitian ini juga menemukan bahwa kesadaran mode memiliki pengaruh yang signifikan terhadap konsumsi busana muslimah di Indonesia. Dengan melihat hasil penelitian ini, diharapkan dapat bermanfaat khususnya bagi produsen dan industri busana muslimah di Indonesia dalam mempertimbangkan strategi yang lebih efektif dalam menarik perhatian konsumen Muslim di Indonesia. Produsen diharapkan mampu memberikan harapan konsumen, terutama bagi konsumen yang religius. Karena konsumen yang religius akan lebih kritis dalam pengambilan keputusan terkait pemilihan model busana dan konsumsi busana muslimah.

Kata Kunci: Religiusitas, Kesadaran Mode, Konsumsi Busana Muslimah

\footnotetext{
${ }^{1}$ Trisakti University Jakarta | mayangsariedastami@gmail.com (Corresponding Author)

${ }^{2}$ Diponegoro University Central Java | Mmiyasto_h@yahoo.com

${ }^{3}$ Perbanas Institute, Jakarta | akhmad.affandi@perbanas.id
} 


\section{Introduction}

The development of a fashion industry in a country reflects the development of the lives of its people, both in terms of ethnic structures and within the scope of cultured and religiosity in these countries. Lately there has been a lot of media presenting various interesting information about the world of fashion in Indonesia. The development of the fashion industry in Indonesia has increased rapidly in the last few decades.

Regarding the halal fashion trade, Indonesia is one of the countries with the largest fashion production in the world. In Indonesia, there are 750,000 small and medium industries that produce fashion and accessories for all people in Indonesia and abroad. 30\% of the fashion manufacturer in Indonesia is dominated by hijab fashion producers (Statistic Center, 2017).

In 2016, Indonesia became the second largest country in the halal fashion consumption segment with a value of consumption reaching 13.5 billion USD (Global Islamic Economic Report, 2016 ). This data indicates that Indonesia is a large enough market for halal fashion industry.

This potential should be utilized to make Indonesia not only as a consumer, but can become a major producer of hijab fashion in the world. Besides that, in terms of the Indonesian economy, the halal fashion industry has a significant contribution to the value of Gross Domestic Product. In 2016, the textile industry sector contributed a percentage of $18 \%$ of Indonesia's total GDP. With the proportion of production from the hijab fashion industry amounting to $30.8 \%$ of the total textile industry output for the year (Statistic Center, 2016).

Table 1 shows that there has been a rapid growth in the hijab fashion industry sector in Indonesia from 2011 to 2016 with a growth rate of more than 50 percent. This shows that consumer interest in hijab fashion products is increasing and the potential that can be developed by this business sector is also increasing. 
TIFBR | Tazkia Islamic Finance and Business Review

Volume 13(1), 2019

Table 1. Gross Domestic Product Data Based on Current Price 2011-2016 (in billions Rupiah)

\begin{tabular}{lcccccc}
\hline & $\mathbf{2 0 1 1}$ & $\mathbf{2 0 1 2}$ & $\mathbf{2 0 1 3}$ & $\mathbf{2 0 1 4}$ & $\mathbf{2 0 1 5}$ & $\mathbf{2 0 1 6}$ \\
\hline GDP & $7,831,726$ & $8,615,705$ & $9,546,134$ & $10,560,705$ & $11,531,717$ & $1,406,854$ \\
Textile and Apparel & 108,192 & 116,558 & 129,912 & 139,032 & 139,394 & 140,849 \\
Industry & 27,048 & $30,687.87$ & $35,076.23$ & $38,928.96$ & $40,424.26$ & $43,663.19$ \\
Hijab fashion Industry & $24.9 \%$ & $26.3 \%$ & $26.9 \%$ & $27.9 \%$ & $28.9 \%$ & $30.9 \%$ \\
Percentage & &
\end{tabular}

Source: Indonesian Economic and Financial Statistics - Bank Indonesia

The plan to increase Indonesia's economic value has been planned by Bank Indonesia. Bank Indonesia together with Bappenas will create a program that encourages the level of production and services from halal industries, including halal fashion. This has become one of the supporting phenomena that proves that the hijab fashion industry is quite promising for improving the Indonesian economy.

Table 2. Top 10 Countries in Halal Fashion Rating Country

\begin{tabular}{cl}
\hline Rating & \multicolumn{1}{c}{ Country } \\
\hline 1 & United Arab Emirates \\
2 & Indonesia \\
3 & Singapore \\
4 & Malaysia \\
5 & Turkey \\
6 & China \\
7 & Italy \\
8 & French \\
9 & Bangladesh \\
10 & Sri Lanka \\
\hline
\end{tabular}

Source: Global Islamic Economic Outlook 2018

Indonesia has a great potential in hijab fashion sector and Indonesia the second of the GIC member states with the highest GIE's rates in the hijab fashion sector. Quality of design and product for hijab fashion industry in Indonesia has also been recognized in the global competition. Indonesia is also the third largest country in the world as hijab fashion consumers (Global Islamic Economic Report, 2018). In connection with this matter, Indonesia can 
take a great chance to find out the hijab fashion trends that are expected by the market, because Indonesian consumers is the third largest market in the world's for halal fashion products.

The trend of fashion products in Indonesia in the 2011-2015 period showed a positive value of 8.15 percent. Meanwhile in terms of export volume, there was an increase in January 2016 of 3.87 percent compared to the same period in 2015. Then, specifically in 2014, the export performance of hijab fashion products was USD 4.63 billion with an export growth trend of 2.30 percent. In 2015, the export performance of hijab fashion products managed to penetrate USD 4.57 billion. While the achievement in January 2016 experienced an increase of 2.13 percent compared to January 2015 from USD 366.2 million to USD 374 million (Indonesian Ministry of Trade, 2016).

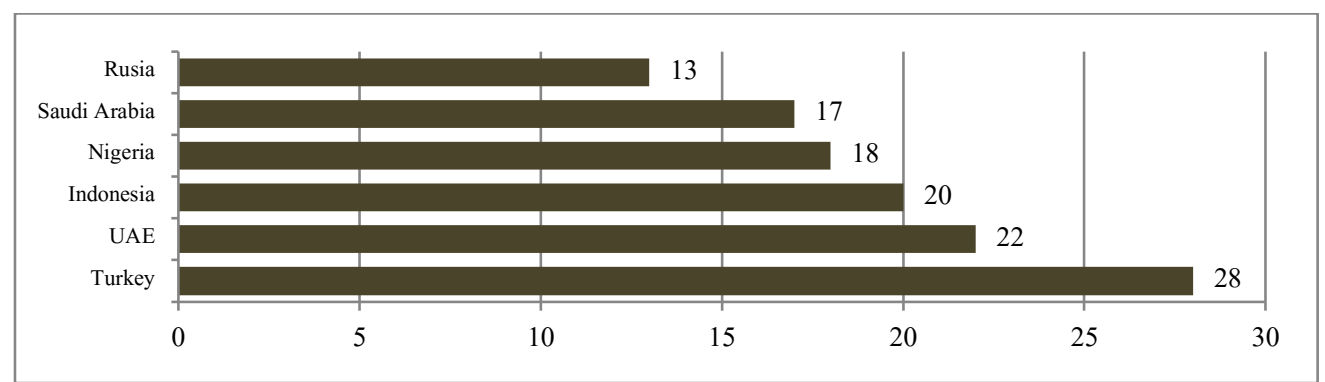

Figure 1. Muslim Countries with the Biggest Halal Fashion Expenditures (In US Billion)

Source: Global Islamic Economic Outlook 2018

The chart above shows the condition of the halal fashion market by measuring total expenditure for the halal fashion sector. From these data can be seen 10 countries that have opportunities the biggest as a destination for world halal fashion marketing. In the rankings, Indonesia became one of the world's largest market for halal fashion market in the world with expenditures amounting to 20 billion USD in 2017. This has become one of the great opportunities for Indonesia when Indonesia is able to understand the conditions of market interest widely by using a sample of consumers from the country of Indonesia itself. 
Based on these conditions, hijab fashion industry in Indonesia requires a study of hijab fashion consumers in Indonesia, so that the industry is able to prepare their plans in global market competition. Because, in the phenomenon that occurs, many hijab fashion manufacturers lack knowledge of market developments, consumer conditions, potentials that can be developed and other things related to the development of the $\mathrm{v}$ fashion industry.

Consumers are an important element in a trading activity because consumers are the main object in these trading activities. So that industry players really need an in-depth study of the motivations and reasons of consumers in choosing the products they offer. This is so that industry players understand the concepts of trade and marketing that are the most appropriate for them to do so that they will be able to attract consumer interest (Sobh, 2013).

Discussed ways about the purpose of a consumer to consume products, religiosity factor is one factor that can determine an attitude, religiosity is an element that is very important to learn because religion is one of the elements which is very universal and powerful for consumer decision. Religiosity has a significant influence on people's attitudes, values and behavior both at the individual and community level in general (Mokhlis, 2006). Then, religion covers every aspect of society and market participants cannot underestimate its influence on consumer behaviour. Unlike other cultural dimensions, religion tends to be stable and static. After understanding this, market participants can believe that the application of this factor in the market industry will bind consumers to the industry (Fam, 2004).

The mode of Islamic lifestyle can be seen as a contradiction to globalization and the style of western consumerism. However, in this case Islam allows the desires of the people if the desire does not conflict with the moral principles set and realized to consume halal goods (Sobh, 2013).

This study will be conducted focusing on hijab fashion consumers. This is because hijab fashion consumers are the highest consumption level in the fashion industry. 
Farraq and Hasan (2015) stated that the level of religiosity will have a negative impact on the awareness of one's consumers in the trend of fashion products in Egypt. In another study, Islam and Chandrasekaran (2016) stated that religiosity has a positive and significant influence on the awareness of hijab fashion in consumers in India. Basically, religiosity is a very basic factor owned by every religious community in the world in the decision making process. Farraq and Hassan (2015) stated that negative effects were obtained due to the high level of religiosity which would cause consumers to buy fashion products only to fulfil basic needs, not to consume large quantities for fashion needs.

In the process of making hijab fashion consumption, consumers have an aspect that is in the form of awareness of fashion that is defined by Nam (2007) as an individual assessment that determines the style of fashion that will be used by these consumers. This is similar to Cass (2015) which stated that consumers are the main party that determines everything related to fashion. The perspective of each consumer regarding his decision to buy a hijab fashion product depends on several things, namely the style of dress, fashion motivation, the uniqueness of fashion and the source of knowledge from consumers themselves on fashion.

In today's modern era, the development of fashion style trends is increasingly rapid in the style of hijab fashion. New models and trends are created in each season that will affect the fashion consciousness from consumers which will then determine the level of consumption of hijab fashion. Different consumer preferences for hijab fashion designs that they will choose for their consumption require producers to continue to create innovations to increase the potential for competitiveness in the market.

The high level of consumer needs for the fulfilment of the dressing style will eventually lead to a special motivation in consumers to determine the fashion model they will use. The role of fashion is currently one of the priorities that is prioritized by women in general. In various conditions, each consumer has specific criteria to determine the style of dress they will use. This will create various motivations from consumers to carry out consumption activities. 
The idea of the style and style of the hijab that can be seen in every gallery or showroom of many hijab fashion manufacturers that shows the uniqueness of various forms of fashion in hijab. The uniqueness and variety of styles of hijab fashion ranging from fashion with asymmetrical pieces, various forms of rectangular headscarves, and pashmina with various models of motifs such as flowers, ethnic batik, polka dots and other motifs that make hijab fashion become more attractive with colour choices fresh and additional accessories with various beautiful models.

Motivation of a consumer in consuming a hijab fashion product can be said to be different, depending on the goals to be achieved by the consumer in choosing the hijab fashion model that he uses. In this developing age, some people prioritize internal motivation from within themselves in realizing a comfort in dressing and prioritizing personal tastes. However, there are also consumers who consider that external motivation is an important thing, namely they need to meet the expectations of the community, use the best fashion to look good in front of the public or with the goal of making other people happy to see it.

The style of hijab fashion that is popular in the current era is certainly very different from the style of hijab fashion that was used in the ancient era. Formerly hijab fashion models were used with models that tended to be simple and monotonous, and looked less attractive. And in the previous era, hijab fashion was only widely used by elderly Muslim women. Today's hijab fashion style has become an important part of the fashion industry in Indonesia. This makes the hijab no longer a difficult consideration for Muslim women in making decisions to wear hijab fashion.

Internet and technological developments bring a considerable change for humans. This has an impact on everyone who is easy to access information without limited time and place. This is used by various parties to carry out various purposes including as a medium of communication and information about hijab fashion which contains a message to invite fellow Muslim women to use hijab and consume hijab fashion products. The phenomenon of the 
development of hijab fashion in Indonesia is not separate from the influence of modern lifestyles that can not be separated from technology. Consumers use the development of information as a means to appreciate themselves. So that what they use can be a reference for other consumers that will have an impact on the decisions of other consumers in buying these products.

The recent rapid globalization has also pushed for a growing level of information dissemination capabilities with various models of information dissemination that will make it easier for consumers to find hijab fashion references that they will use. The information in question can be in the form of information about trendy fashion models, the best fashion materials, breakthroughs in multifunctional fashion models or information on the tastes and interests of the people in the fashion models that are currently preferred. The information they obtain tends to influence their decision making in consuming a fashion product.

Hijab Fashion Consciousness is also influenced by more creative ideas that emerge from Hijab fashion designers and manufacturers who create unique fashion models that add choices for consumers to consume fashion products. Consumers tend to be more happy to consume unique products that are not widely used by other consumers.

Hassan and Harun (2015) in their research stated that fashion consciousness has a positive influence on the level of consumption of hijab fashion in Malaysia. And the factors that have a significant influence on fashion consciousness are dressing style, fashion motivation, fashion uniqueness and source of fashion knowledge.

Based on the above discussion, the research questions of this study can be formulated in the form of questions of this study as follows: How does religiosity affect hijab fashion consciousness in Muslim fashion consumers in Indonesia? How does the dressing style affect hijab fashion consciousness in Hijab fashion consumers in Indonesia? How does the source of knowledge affect hijab fashion consciousness in Hijab fashion consumption in Indonesia? How is the influence of fashion motivation affect hijab fashion consciousness 
in Hijab fashion consumers in Indonesia? How does fashion uniqueness affect fashion hijab consciousness in Hijab fashion consumers in Indonesia? How does hijab fashion consciousness affect the consumption of Hijab fashion in Indonesia?

\section{Literature Review}

Muhammad (2004) stated that Muslim consumers are a group of consumers with behavior where in meeting their needs not only meets individual needs (material), but also meets social (spiritual) needs. Muslim consumers when they get their regular, weekly, monthly, or annual income, they don't think the income they have earned must be spent on themselves, but because of their awareness that they live to seek pleasure.

Fashion consciousness refers to the level of involvement of a person with the style or fashion of the clothes they uses. An individual does not have to be a determinant in fashion or fashion innovators to be considered as someone who has fashion consciousness. In contrast, the fashion consciousness characterized by a consumer interest in fashion and fashion trendy in one's appearance (Hassan and Harun, 2015). Lumpkin (2005) found that most adult consumers will use their ability to consume products by buying clothes, and therefore it can be concluded that segments that have fashion consciousness are indeed among adult fashion buyers. Similarly, women who have fashion consciousness often feel younger than their age. However, no relationship was found between age perception and fashion consciousness.

Hassan and Harun (2015) define dressing style as a variable that will assess the behaviour of fashion industry consumers by judging that a consumer has a comfortable feeling when using a particular fashion model. Then in the same study, it was also explained that the urgency or interest of someone in liking a model of fashion included the definition of dressing style. Consumers feel the need to observe the latest trends in a fashion model aimed at supporting their desires in fashion, so that they will have many of the fashion models that they collect as a form of interest they like (Hassan and Harun, 2015). 
Source of Knowledges are explained into several sources, namely sources originating from product catalogues, consumer observation processes, store displays, information from relatives, information from the media in the form of magazines, marketing activities in the form of fashion shows and fashion fair (Hassan and Harun, 2015). According to Kotler and Keller (2016), information is an important part of the process of perceptions of awareness and decisions of a consumer where this is a process that is used by individuals to choose, organize, and interpret information input to create a picture. Perception does not only depend on physical stimulation but also on stimuli related to the surrounding environment and the circumstances of the individual concerned.

Fashion Motivation is defined as the motive carried out by consumers when consuming a fashion product for reasons of comfort, the specific purpose when using fashion mode, to show personality and identity through the fashion model used, and the motive for mixing with relationships (Hassan and Harun, 2015).

Fashion Uniqueness is defined by the characteristics of a consumer who likes things that are different from other consumers, then the consumer wants to be a pioneer in a fashion model and likes the difference in the fashion model he uses (Hassan and Harun, 2015). This uniqueness factor is also formed based on the personality possessed by each consumer where each person has a variety of different personality characteristics that can affect the activities of his purchasing activities. Personality is a different human psychological trait that results in a relatively consistent and long-lasting response to environmental stimuli. Personality is usually illustrated by using traits such as self-confidence, dominance, social ability, self-defence and ability to adapt. Personality can be a very useful variable in analysing consumer brand choices. This is because some consumers will choose a brand that matches their personality.

In general, Glock in Islam and Chandrasekaran (2016) said that there are five aspects in religiosity, namely:

First, Belief (The ideological dimension). Religiosity Belief (The ideological dimension) or also called faith dimension is the degree to which a 
person accepts dogmatic things in religion, such as belief in God, angels, heaven and hell. Although it must be admitted that every religion certainly has a set of beliefs that are different from other religions, even for their own religion a different understanding emerges and is not often opposed. Basically every religion also wants an element of obedience to each of its followers, so the dimension of belief is more doctrinal which must be obeyed by followers of religion. For example, the dimension of belief in Islamic religion embodied in confession (syahadat) is realized by reading two sentences of creed, that there is no God but Allah and the Prophet Muhammad is the messenger of Allah.

Second, practice (The ritual dimension). Religiosity practice (The ritual dimension), which is the degree to which someone carries out the obligation of worship in his religion, the elements that exist in this dimension are cults and things that better show one's commitment in the religion he adheres to. The manifestation of this dimension is the behavior of the followers of certain religions in carrying out rituals related to religion. For example, the practical dimension in Islamic religion can be done by performing worship services, fasting, almsgiving, pilgrimage or other muamalah practices.

Third, Feeling (The experiential dimension). Religious Feeling (The experiential dimension) or so-called dimension of experience is the feeling or experience that has been experienced and felt, for example feeling close to God, feeling afraid of sinning, feeling his prayer granted, saved by God and so on. In Islam this dimension can be manifested in a feeling of being close or familiar with Allah, feeling trustful (surrendering to a positive thing) to Allah, Feeling solemn when performing Prayers and praying, feeling thrilled when hearing the call to prayer or the verses of the Qur'an. Persaan thank God, the feeling of getting a warning or help from God.

Fourth, knowledge (The intellectual dimension). Religious knowledge or the dimension of religious knowledge is a dimension that explains how far someone knows about the teachings of his religion, especially those in any other scriptures, at least someone who is religious must know the main things about the basic beliefs, scriptures and traditional traditions. This dimension in 
Islam refers to the level of knowledge and understanding of Muslims towards their religious teachings, especially regarding the basic teachings of their religion, as contained in their scriptures.

Fifth, effect (the consequential dimension). Religious Effect (The consequential dimension) is a dimension that measures the extent to which a person's behavior is based on religious teachings in social life.

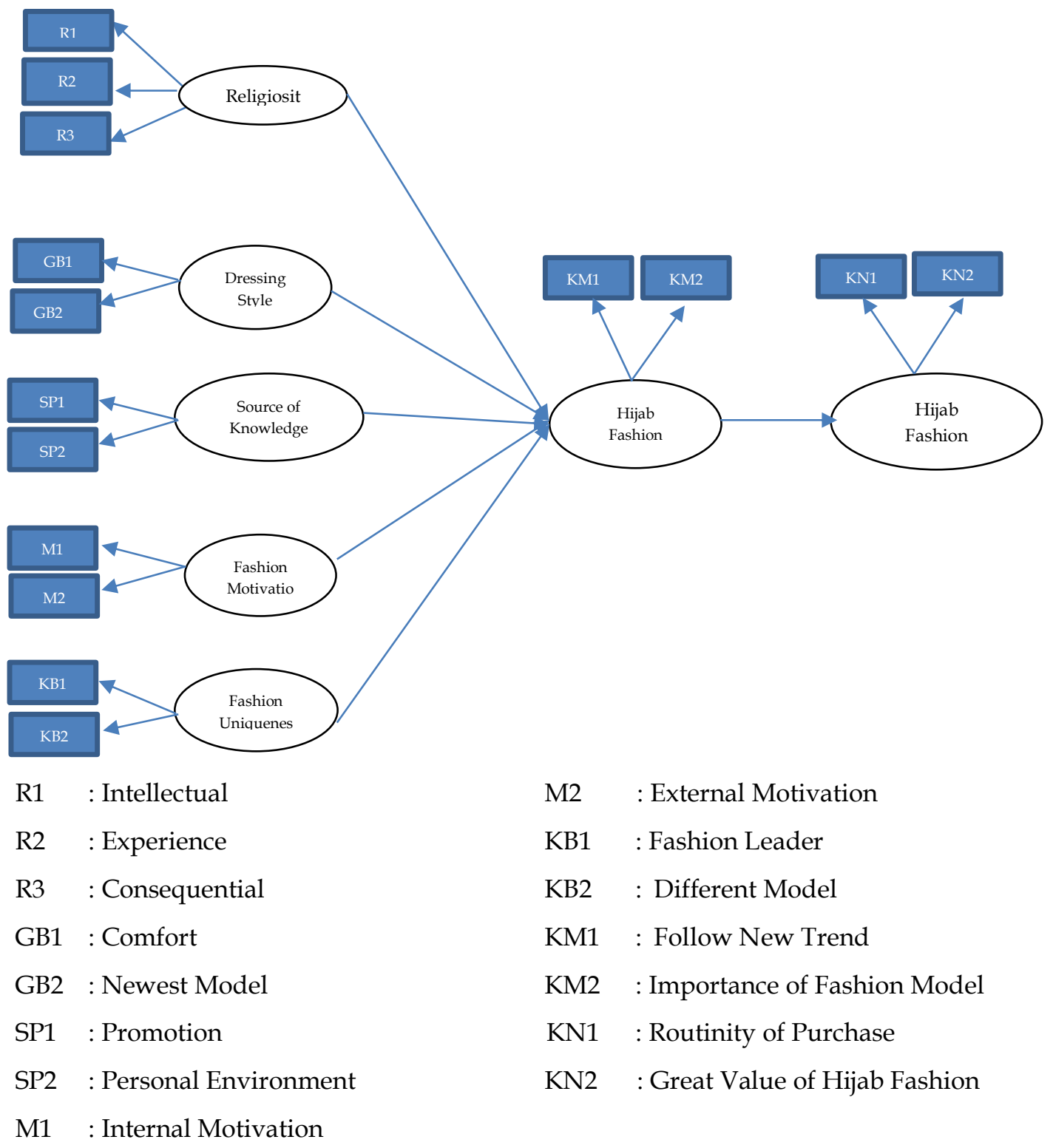

Figure 2. Conceptual Framework

\section{Effect of Religiosity on Hijab Fashion consciousness}

O'Cass et al. (2013) discussed the moderate role of religiosity on the relationship between one's consumption status and fashion consciousness in 
Iranian society and find that there is an inverse relationship between consumption status and religiosity, in which an individual's fashion consciousness depends on their level of religiosity and their level of awareness of understanding choices. Islam and Chandrasekaran (2015) state that one's religiosity will have a positive influence on the level of awareness in consuming a product. Because religiosity is a dimension of obedience that has a spiritual impact on consumers in the process of making decisions and awareness that they have in view of a product.

\section{H1: Religiosity has a positive effect on fashion consciousness}

\section{Effect of Dressing Style on Hijab Fashion consciousness}

The styles of fashion that used by the consumer can shows their personality. Dressing styles describe an individual's interest in fashion (Wan et al., 2007). Once consumers follow a certain style of fashion, they will be seen as a part of a group. Fashion group members are individuals who choose their model of fashion style in the same way and have the same mindset. Certain designers, producers, and distributors can be considered leaders of the fashion group (Brannon, 2010). However, consumers as unique individuals may have their own perceptions of a particular style, and their personal dressing style may reflect that interpretation.

Wan et al. (2007) explained a correlation between dressing style and fashion consciousness. The choice of fashion and how these choices complement individual features and styles show their self-concept (Piacentini and Mailer, 2004). Dressing style can then be considered as a powerful tools to improve self-image. Consumers who have a high concern for their dressing style are expected to be very aware and follow the fashion trend.

H2: Dressing style has a positive effect on fashion consciousness

\section{Effect Source of Knowledge on Hijab Fashion consciousness}

Consumers look for information to minimize risks and uncertainties in purchasing decisions. Knowledge of modes can be obtained in various ways. 
Consumers can obtain information from individuals (Kinley et al., 2000). Engel et al. (2017) categorize sources of information that come from individuals (eg friends, parents, siblings, and salespeople) and professionals (eg, mass media, sales promotions and store displays). Cox and Rich (2014) categorize information sources as predominantly market sources, neutral sources (eg consumer magazines and reports) and personal sources (eg family and friends). Consumers add their knowledge as information on various media and store displays, because reference from other parties only provides part of the information. Therefore, information sources are often combined to increase consumer confidence.

With regard to fashion, consumers are becoming aware of new fashion styles by identifying fashion information sources (Nam et al., 2007). The amount of time and effort wasted in fashion information can form attachments or relationships between consumers and fashion (Cardoso et al., 2010). Ibrahim (2011) found that fashion conscious consumers rely more on information from the mass media than fashion-conscious consumers. Nam et al. (2007) found that catalogues, social gatherings, store displays, fashion magazines and friends were important sources of information for new fashion trends. Therefore, information sources tend to have a positive relationship with fashion consciousness. In other words, individuals who have more sources of fashion knowledge tend to be more fashion conscious.

\section{H3: Source of Knowledge has a positive effect on fashion consciousness}

\section{Effect of Fashion Motivation on Hijab Fashion consciousness}

Motivation is defined as the reason for the underlying behaviour (Guay et al., 2010). Gredler defines motivation as a characteristic that drives us to do something or not. Motivation includes beliefs, perceptions, values, interests and actions that are very close (Lai, 2011). Furthermore, many methods for studying motivation emphasize cognitive behaviour (e.g. use of monitoring and strategy), non-cognitive aspects (e.g. perceptions, beliefs and attitudes) or both. Motivation regulates behaviour that is distinguished by readiness and 
free will. In the context of consumer behaviour, motivation produces a desire or need for a product (Engel et al., 2017).

Previous research has identified motivating consumers to buy clothes. Preliminary studies have identified the protection of the physical, social and psychological environment as a motivation for buying clothes (Engel et al., 2017) showing that fashion plays an important role in presenting the desired image and lifestyle. Consumers express their identity to adjust to their expressions (Engel et al., 2017). Chen-Yu and Seock (2002) found that conformity and recognition were important motivations for purchasing teenage fashion. The normative influence on fashion for individuals is important in the sense that fashion choices need to be liked by their colleagues (Auty and Elliott, 2001). Then, Nam et al. (2007) identified hedonic needs for personal pleasure and the utilitarian needs of fashion that are suitable for the season or important as adult consumers in buying fashionable clothes. In the current study, fashion conscious consumers have a strong motivation for fashion. This motivation is driven by the way they purchase their fashion groups by reflecting their good tastes and public status (Khare et al., 2012).

\section{H4: Fashion motivation has a positive effect on fashion consciousness}

\section{Effect of Fashion Uniqueness on Hijab Fashion consciousness}

Uniqueness refers to the tendency of consumers to have unique products to be different from others (Tian et al., 2001). The need for uniqueness makes consumers look for consumer goods, services and experiences that some others have (Workman, 2007). This goal is manifested openly and can be observed in behaviour (Workman and Kidd, 2000). People who find their level of uniqueness inadequate to engage in consumption activities, such as shopping for fashionable clothes, to satisfy their perceptions of uniqueness (Burns and Warren, 2015). The importance of uniqueness is more prominent in products such as fashion, because it is consumed publicly and serves as a means of expressing self-expression (Jin and Son, 2013). According to Workman and Caldwell (2007), fashion consumer groups differ in their sensitivity to changes 
in aesthetic rules and tend to manipulate aesthetic codes to distinguish themselves from others. According to Dlodlo (2014), the need for uniqueness is positively related to fashion innovation. In hijab mode, each designer or retailer has his own signature style that must be known to others. Hijab fashion has many designs and styles that appeal to consumers and has formed a collection of followers. With a better understanding of the concept of Islamic fashion, Muslim women become bolder in experimenting with the way they dress (Wilson, 2013), by mixing and matching what they wear. This creativity and uniqueness has resulted in Hijab fashion becoming more attractive and fashionable.

H5: Fashion Uniqueness has a positive effect on fashion consciousness.

\section{Effect of Hijab Fashion consciousness on Consumption of Hijab fashion}

The degree of individual involvement in fashion style or mode is known as fashion consciousness (Nam et al., 2007). O'Cass et al. (2013) define fashion conscious consumers as people who are very involved with everything about fashion. Fashion consciousness describes a person's awareness of fashion and the ability to choose, dress together or imitate and be responsive to fashion (Milewski, 2005). According to Wan et al. (2007), many studies have explained that fashion consciousness is a significant construction that defines loyal consumers who are aware of their image and physical attractiveness.

However, fashion conscious consumers do not mean that they are experts or pioneers in the fashion industry, but they are aware of their appearance and try to remain principled (Hassan and Harun, 2015). Fashion conscious consumers pay more attention to current trends, keep on updating their fashion collections and enjoy shopping. They tend to absorb images and fashion styles that are promoted in advertising (Wan et al., 2007).

H6: Fashion consciousness has a positive effect on Hijab fashion consumption. 


\section{Method}

This research analyses examine the influence of fashion consciousness as a mediating factor on hijab fashion consumption in Indonesia. The population of this research is the hijab fashion consumers in Jakarta who are using hijab at least 2 years. The number of samples taken are 483 people. The collection of data carried out by interviewing the consumer sample using a questionnaire. The variables used in this study are religiosity, dressing style, fashion motivation, source of knowledge, fashion uniqueness, fashion consciousness and hijab fashion consumption.

The data that have been collected were tested using validity and reliability test as instrument testing to show the relation between indicators and to the variables itself. The next step is testing the model fit of the research, this testing used to analyze the quality of the model that used in the research. After verification testing hypotheses using structural equation model analysis with AMOS software tools and SPSS are conducted. Whereas, Structural equation modelling is a multivariate statistical analysis technique that is used to analyze structural relationships. This technique, which is the combination of factor analysis and multiple regression analysis, and it is used to analyse the structural relationship between measured variables and latent constructs (Hermawan, 2006). This method is very suitable because it can measure the influence of each variable without eliminating the influence of each indicator. In addition, the use of SEM will make it possible to see the effects directly and indirectly. In addition, this method is indeed suitable for use in data involving using a perception scale.

\section{Results and Discussion}

Table 3. Hypothesis Testing Results

\begin{tabular}{lrlrr}
\hline & \multicolumn{2}{l}{ Hypothesis } & Effects & \multicolumn{1}{c}{ P } \\
\hline Religiosity & $\rightarrow$ & Fashion Consciousness & -.182 & .018 \\
Dressing Style & $\rightarrow$ & Fashion Consciousness & .261 & .018 \\
Source Of Knowledge & $\rightarrow$ & Fashion Consciousness & -.272 & .355 \\
Fashion Motivation & $\rightarrow$ & Fashion Consciousness & .967 & .001 \\
Fashion Uniqueness & $\rightarrow$ & Fashion Consciousness & -.274 & .260 \\
Fashion Consciousness & $\rightarrow$ & Hijab Fashion Consumption & .928 & $\star * *$ \\
\hline
\end{tabular}




\section{Effects of Religiositiy on Hijab Fashion Consciousness}

Based on Table 3 mentioned above, it can be stated that the significance value for this hypothesis is of 0.01 which in this study is used alpha $5 \%$ so that the significant value of this hypothesis is the smaller of the alpha value. However, the direction that results from testing this hypothesis is negative, 182. Therefore, it can be concluded that Ho is accepted and Ha is rejected. Thus it can be concluded that there is no significant positive effect of religiosity on fashion consciousness in hijab fashion consumers in Indonesia. Because the effect produced is a significant negative effect of the variable religiosity on fashion consciousness.

\section{Effect of Dressing style on Hijab Fashion Consciousness}

Based on table 3 above, it can be seen that the significance value of the effect of dressing style on fashion consciousness is 0.01 where this study uses alpha $5 \%$ so that this significance value is less than alpha so Ho is rejected and Ha is accepted. In other words there is a significant positive effect of dressing style variables on fashion consciousness in hijab fashion consumers in Indonesia.

\section{Effect of Source of Knowledge on Hijab fashion Consciousness}

Based on table 3, it can be seen that the significance value of this hypothesis is 0.35 where the alpha in this study is 0.05 so the significance value is above alpha. Therefore, it can be stated that Ho is accepted and Ha is rejected. Thus it can be stated that there is no significant influence from sources of knowledge on the awareness of fashion in hijab fashion consumers in Indonesia.

\section{Effects of Dress Fashion Motivation on Hijab fashion Consciousness}

Based on table 3, it can be seen that the significance value for this fourth hypothesis is 0.001 where the alpha value for this study is 0.05 , so the significance value is less than the alpha value. Therefore it can be concluded that Ho is rejected and Ha is accepted. So that it can be stated that there is a 
significant influence on the fashion motivation to hijab fashion consciousness in hijab fashion consumers in Indonesia.

\section{Effect of Fashion Uniqueness on Hijab fashion consciousness}

Based on table 3 above, it can be seen that the significance value of the hypothesis is 0.26 , where the alpha used in this study is $5 \%$ so that the significance value is greater than the alpha value. Because it was concluded that Ho was accepted and Ha was rejected. Thus it can be formed a statement that fashion uniqueness does not have a significant influence on hijab fashion consciousness in hijab fashion consumers in Indonesia.

\section{Effect of Hijab Fashion consciousness on Hijab fashion Consumption}

Based on the table above, it can be concluded that the significance of the effect of fashion consciousness on hijab fashion consumption in Indonesia is 0,000 so that this significance value.

Awareness of fashion in dress is a condition where a fashion consumer has an interest and concern at a certain level with fashion that will be purchased or will be used. In general, awareness of this mode will be strongly associated with the development of fashion from fashion that is happening in the environment of these consumers. In general, the level of awareness of this mode will be a barometer for a hijab fashion producer in finding the market that he will enter. The awareness of this mode in the wider community will be more easily found among female consumers, because of the tendency of consumers to focus more on their appearance and comparing their appearance with others.

In practice, fashion consciousness from a consumer, especially women, can be influenced by many factors such as the current dressing style, fashion motivation in using certain fashion, sources of knowledge held in connection with certain fashion modes (Hassan and Harun, 2015). In addition, other factors that are most important are certain values that are recognized or adopted by a particular group of people.

Dressing style tends to have a positive influence on fashion consciousness, because consumers with decisions that take into account the 
style of dress they will use, tend to pay close attention to the type of hijab fashion that will be consumed. So that it will increase the awareness of the consumer in question regarding the mode of the Muslim woman he uses. In this study it was found that the motivation of a hijab fashion consumer has a very strong influence on fashion consciousness. Motivation in fashion is a factor that has the strongest influence on awareness of fashion.

Religiosity is a factor that has a significant influence on fashion consciousness. This factor has a negative effect (in table 3). O'Cass et al. (2013) found that there is an inverse relationship between consumer awareness and religiosity, where fashion consciousness of an individual depends on their level of religiosity and their level of awareness in understanding their choices. The nature of religiosity can provide a set of standards to assess and guide one's behaviour. However, this behaviour depends on the strength of one's commitment to his religion and on the level of his compliance with certain religious rules.

Mukhlis (2006) explained that in this case, religious consumers tend to have a lower risk when shopping and give greater emphasis on quality when choosing a product. In addition, O'Cass (2013), found that religious consumers tend to be less materialistic (Burroughs and Rindfleisch, 2002) because they view material objects as barriers to spiritual transcendence. Alam et al., (2011) reinforce this with the statement that Muslims consider Islam as a source of their reference and they do shopping to meet religious needs as ordered by God in the Qur'an.

In addition, this religious factor itself is a factor that has a negative influence. This can occur due to several things, the first is the role of religiosity in Muslim fashion is related to the rules and boundaries where these rules and limits will certainly reduce the level of fashion awareness in a Muslim. Furthermore, in Islam it is highly recommended to live a simple and modest life. This will also weaken the awareness of a Muslim woman in fashion. And the last is on the concept of Islam the function of fashion is as a cover of genitalia 
where this shows the involvement of fashion in the teachings of Islam so that concern for this mode will also be lacking.

Besides that, consumers who have a high level of preference to the uniqueness tends to not have any involvement in the conduct of consumption activities, to satisfy their perceptions about the uniqueness (Burns and Warren, 2015). The importance of uniqueness is more prominent in products such as fashion, because it is consumed publicly and serves as a means of expressing self-expression (Jin and Son, 2013).

The source of knowledge is the second factor that does not have a significant influence on fashion consciousness. This is possible because the habits of Indonesian buyers in buying clothes are that fashion is an item where consumers do not search for information that is truly in the selection before purchase. Where in the habit in Indonesia, a consumer will immediately come to the shops then immediately ask there and immediately decide to buy or not buy. In certain product marketing practices, consumers do not take advantage of information on the development of models of products that are distributed, because one of the main factors they follow is the function, needs and fulfilment of criteria and regulations in their trust in the use of a product.

Then, in terms of hijab fashion, a consumer tends to prefer to choose the decision to buy a product when looking at the product directly. This is related to the level of development of information technology that currently exists, most of them are able to provide information on a hijab fashion model. However, the suitability of materials and sizes available at the source of information provided by social media is still not appropriate. So consumers tend to still prefer to see directly and compare products from a store with another store when they are shopping in a shopping center. But keep in mind that, in the future, the renewed strength of information and media will most likely be able to meet the needs of consumers in terms of information so that they will feel satisfied with the information they get about a product. However, in this period of development there are still many things that need to be 
considered by the hijab fashion industry activists in developing and attracting consumers' interest through the media information they provide.

\section{Conclusion}

The study found that religiosity has a significant impact on hijab fashion consciousness, However, the influence of religiosity has a negative effect which means that the more religiosity level of a customer, she will be has a lower level of hijab fashion consciousness. On the other hand, dressing style and fashion motivation have positive and significant impact on fashion consciousness, thus this is in accordance with existing theories. In This study also found that the fashion uniqueness and source of knowledge have no significant impact on hijab fashion consciousness. Then, for the main hypothesis, there is s positive significant impact from hijab fashion consciousness to hijab fashion consumption in hijab fashion consumer in Indonesia.

This study implies, that even though hijab fashion is a religious product, it does not mean that a religious person will buy hijab fashion more often. Furthermore, the fashion uniqueness is not a consideration for some hijab fashion consumers. Then, in this study it was found that for consumers of hijab fashion in Indonesia, the source of knowledge is not a factor that influences the hijab fashion consciousness and the level of consumption of hijab fashion. This is a different result from previous studies with the object of research on hijab fashion consumers in other countries.

\section{References}

Auty, S.G., and Elliott, R. (2001). Being Like or Being Liked: Identity vs Approval in a Social Context. Advances in Consumer Research, Vol. 28(1): 235-241.

Brannon, E.L. (2010). Fashion Forecasting, Fairchild Publications, New York, NY.

Burns, D.J. and Warren, H.B. (2015). Need for Uniqueness: Shopping Mall Preference and Choice Activity. International Journal of Retail $\mathcal{E}$ Distribution Management, Vol. 23(12): 4-12.

Cardoso, P.R., Costa, H.S. and Novais, L.A. (2010). Fashion consumer Profiles in The Portuguese Market: Involvement, Innovativeness, Self- 
Expression and Impulsiveness As Segmentation Criteria. International Journal of Consumer Studies, Vol. 34(6): 638-647.

Chen-Yu, J.H. and Seock, Y.K. (2002). Adolescents' Fashion Purchase Motivations, Information Sources, and Store Selection Criteria: A Comparison of Male/Female And Impulse/Nonimpulse Shoppers. Family and Consumer Sciences Research Journal, Vol. 31(1): 50-77.

Engel, J.F., Blackwell, R.D. and Miniard, P.W. (2017). Consumer Behaviour, 10th ed., Dryden, Chicago, IL.

Fam, K.S., Waller, D.S. and Erdogan, B.Z. (2004). The Influence of Religion on Attitudes Towards The Advertising of Controversial Products. European Journal of Marketing, Vol. 38(5/6): 537-555.

Farraq and Hassan. (2015). The Influence of Religiosity on Egyptian Muslim Youths' Attitude Towards Fashion. Journal of Islamic Marketing, Vol.6: 95-108.

Guay, F., et al. (2010). Intrinsic, Identified, and Controlled Types of Motivation for School Subjects in Young Elementary School Children. British Journal of Educational Psychology, Vol. 80(4): 711-735.

Hassan and Harun. (2015). Factors Influencing Fashion Consciousness in Hijab Fashion Consumption Among Hijabistas. Journal of Islamic Marketing, Vol. 7(4).

Ibrahim, N.A., Ghazali, Z. and Zakaria, Z. (2011). The Influence of Socialization Agents on Fashion Consciousness. International Journal of Business and Social Science, Vol. 2(14): 127-134.

Islam and Chandrasekaran. (2016). Effect of Religiosity on Ecologically Conscious Consumption Behaviour. Journal of Islamic Maketing, Vol. 7(4): 495-507.

Jin, B. and Son, J. (2013). Face Saving, Materialism, and Desire for Unique Apparel Products: Differences Among Three Asian Countries. The Journal of The Textile Institute, Vol. 105(3): 304-313.

Kotler, P. and Keller, K.L. (2016). Marketing Management 15th Edition. London : Pearson

Khare, A., Parveen, C. and Mishra, A. (2012). Influence of Normative and Informative Values on Fashion Fashion Involvement of Indian Women. Journal of Customer Behaviour, Vol. 11(1): 9-32.

Milewski, J.A. (2005). Fashion and The Culture of Consumption: Perceptions of Fashion Trends Among College Students. Paper Presented at The Annual Meeting of The American Sociological Association, Marriott Hotel, Loews Philadelphia Hotel, Philadelphia, PA.

Muhammad. (2004). Ekonomi Mikro dalam Perspektif Islam, cet ke 1. Yogyakarta: BPFE-Yogyakarta: 162 
Mokhlis, S. (2006). The Effects of Religiosity on Shopping Orientations: an Exploratory Study in Malaysia. Journal of the American Academy of Business, Vol. 9(1): 64-74.

Nam, J., et al. (2007). The Fashion-conscious Behaviours of Mature Female Consumers. International Journal of Consumer Studies, Vol. 31(1): 102108.

O'Cass, A., Lee, W.J. and Siahtiri, V. (2013). Can Islam and Status Consumption Live Together in The House of Fashion Fashion? Journal of Fashion Marketing and Management, Vol. 17(4): 440-459.

Sobh, R., Belk, R.W. and Wilson, J.A.J. (2013). Islamic Arab Hospitality and Multiculturalism. Marketing Theory, Vol. 13(4): 443-463

Tian, K.T. and McKenzie, K. (2001)L The long-term Predictive Validity of The Consumers' Need for Uniqueness Scale. Journal of Consumer Psychology, Vol. 10(3): 171-193.

Uma and Chandrasekaran. (2015). Effect of Religiosity on Ecologically Conscious Consumption Behaviour. Journal of Islamic Marketing, Vol. 7: 495-507

Wilson, J.A. (2013). Are Ninjabis the New Punk-Rockers? Huffington Post, available at: www. huffingtonpost.co.uk/jonathan-aj-wilson/areninjabis-the-new-punk_b_4315438.html

Workman, J.E. and Caldwell, L.F. (2007). Centrality of Visual Product Aesthetics, Tactile and Uniqueness Needs of Fashion Consumers. International Journal of Consumer Studies, Vol. 31: 589-596.

\section{Appendix}

\section{Appendix 1. SEM Model}

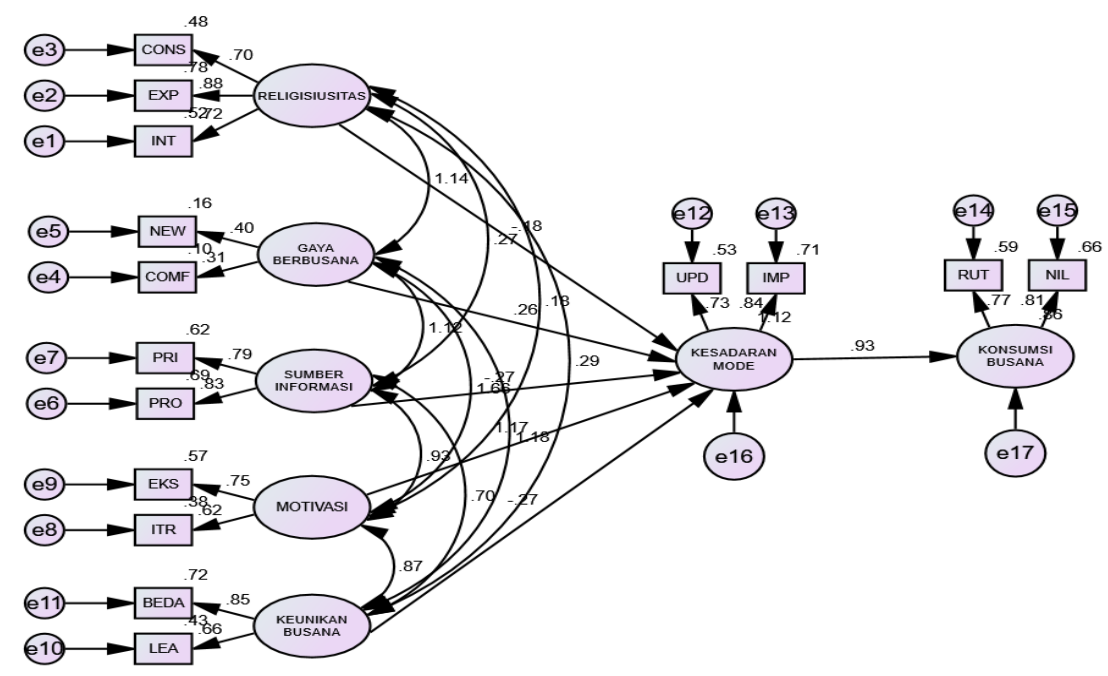


TIFBR | Tazkia Islamic Finance and Business Review

Volume 13(1), 2019

Appendix 2. Standardized Regression Weights

\begin{tabular}{lllr}
\hline & & & Estimate \\
\hline Religiosity & $\rightarrow$ & Fashion Consciousness & -.182 \\
Dressing Style & $\rightarrow$ & Fashion Consciousness & .261 \\
Source Of Knowledge & $\rightarrow$ & Fashion Consciousness & -.272 \\
Fashion Motivation & $\rightarrow$ & Fashion Consciousness & 1.167 \\
Fashion Uniqueness & $\rightarrow$ & Fashion Consciousness & -.274 \\
Fashion Consciousness & $\rightarrow$ & Hijab Fashion Consumption & .928 \\
Religiosity & $\rightarrow$ & Int & .719 \\
Religiosity & $\rightarrow$ & Exp & .884 \\
Religiosity & $\rightarrow$ & Cons & .695 \\
Dressing Style & $\rightarrow$ & Comf & .311 \\
Dressing Style & $\rightarrow$ & New & .398 \\
Source Of Knowledge & $\rightarrow$ & Pro & .832 \\
Source Of Knowledge & $\rightarrow$ & Pri & .786 \\
Fashion Motivation & $\rightarrow$ & Itr & .618 \\
Fashion Motivation & $\rightarrow$ & Eks & .752 \\
Fashion Uniqueness & $\rightarrow$ & Lea & .657 \\
Fashion Uniqueness & $\rightarrow$ & Beda & .849 \\
Fashion Consciousness & $\rightarrow$ & Upd & .730 \\
Fashion Consciousness & $\rightarrow$ & Imp & .845 \\
Hijab Fashion Consumption & $\rightarrow$ & Rut & .766 \\
Hijab Fashion Consumption & $\rightarrow$ & Nil & .813 \\
\hline
\end{tabular}

